\title{
Study of Lead Toxicity Mitigation in Soil in the Presence of Organic Matter
}

\author{
N. Mollazadeh
}

\begin{abstract}
Soil contamination with lead $(\mathrm{Pb})$ has become a common problem in many farmlands and natural ecosystems as well. Thus, the contamination of food produced in those farms has become a serious concern. For the study, twenty-four permanent plots were chose in the forested area. Three treatments, addition of compost, mycorrhizae, compost with mycorrhizae, and a control used. The indicator plant that used to identify the response to soil $\mathrm{Pb}$, was Anthemis Anthemis. Treatments applied to 5 randomly selected Anthemis Anthemis of approximately $0.5 \mathrm{~m}$ height residing in each plot. Soluble soil $\mathrm{Pb}$ and soil organic matter (SOM) compared using soil samples collected at $0.20 \mathrm{~m}$ depth level. Soil samples collected three times. Foliar samples from "treated" plants analyzed for $\mathbf{P b}$. During the experimental period, the selected samples closely monitored and changes in health were duly recorded. Effect of standard compost and mycorrhizae on protecting samples from stressful conditions was significant $(p<0.001)$. The results from soil and foliar analysis revealed the status of $\mathrm{Pb}$ contamination during rain, which appears to have links with the death of Anthemis Anthemis plants. Positive correlations between soil $\mathrm{Pb}$ and leaf $\mathrm{Pb}$ were significant $(p=0.001)$. Soil amendment with compost and mycorrhizae reduced the $\mathrm{Pb}$ content below the threshold levels $(p=<0.001)$. Application of compost and mycorrhizae appeared to be effective in reducing $\mathrm{Pb}$ toxicity in the soil. Soil improvement with standard compost and mycorrhizae appears to be effective in treating contaminated soils with $\mathbf{P b}$.
\end{abstract}

Index Terms-Golestan, soil contamination, lead, compost, mycorrhizae.

\section{INTRODUCTION}

Heavy metals contamination is a major problem of our environment and they are the major contaminating agents of our food supply [1]. This problem is receiving more and more attention all over the world, in general and in developing countries in particular. The biological half-lives of these heavy metals are long and have potential to accumulate in different body organs and thus produce unwanted side [2]. Lead is the most toxic and the most abundant metals in food. Excessive accumulation of these heavy metals in human bodies creates the problems like cardiovascular, kidney, nervous and bone diseases [1], [3]. Contamination of soil with lead has occurred on a global scale. Exposure to lead may cause adverse effects to human health and the environment. Heavy metals such as $\mathrm{Pb}$ become toxic when they do not metabolized by the body and end up accumulating in the soft tissues. Ingestion is the most

Manuscript received June 11, 2014; revised October 15, 2014

N. Mollazadeh is with the Department of Environment, Najafabad Branch, Islamic Azad University, Isfahan, Iran (e-mail: Nastaran.mollazadeh@yahoo.com). common route of exposure to $\mathrm{Pb}$. In plants, uptake of $\mathrm{Pb}$ depends on the plant species and bioavailability of $\mathrm{Pb}$ in the soils. Since most of the ingestion of $\mathrm{Pb}$ occurs from consumption of plants, then addressing how $\mathrm{Pb}$ become unavailable for plants can aid in controlling $\mathrm{Pb}$ toxicity. High concentrations of heavy metals in soils often characterize industrial and postindustrial regions. Sites located around the smelting industries

may have extremely high levels of toxic metals accumulated in soil, particularly in the upper layers. Although the levels of toxic pollutants emitted into the atmosphere have decreased, heavy metals accumulated in soils may persist and affect terrestrial ecosystems for a long time. Vehicle emission where $\mathrm{Pb}$ containing gasoline is used contributes to toxic metal and soil pollution. For busy roads, $\mathrm{Pb}$ levels in soil and vegetation indicated a significant level of $\mathrm{Pb}$ pollution in the areas nearby [3]-[5]. One study has proved the presence of many trace metals in both leaded and unleaded petrol, diesel oil anti-wear substances added to lubricant, brake pads and tires and emission of them through vehicle exhaust pipes. A great part of metal pollutants are deposited in adjacent soils, where they may be transformed and transported to other parts of the environment, e.g., to vegetation. In addition to soil, forest vegetation in particular acts as a sink for atmospheric pollutants because of its capacity to act as an efficient interception to airborne matter [6]. Soil organic matter (SOM) is, together with soil $\mathrm{pH}$, the most important parameter controlling toxic metal behavior in soils. Toxic metals bound on insoluble humic substances (i.e. an important fraction of SOM) are relatively immobile. On the other hand, binding on smaller organic molecules may increase metal mobility and bioavailability (e.g. [7]). Sorption sites on organic matter can be highly specific [8], [9] reported high ability of $\mathrm{Pb}$ to form complexes with insoluble humic substances of low molecular weight. Humic carboxylic - $\mathrm{COOH}$ and phenolic-OH groups are mainly involved in the formation of metalhumic complexes [10]. The strength of metalhumic complexes influenced by soil $\mathrm{pH}$ and ionic strength [8], [11] and [12]. Binding on humic acids may enhance metal sorption on mineral particles [13]. Detailed knowledge of the interaction of toxic metals with humic substances in soils could be used in the development of remediation methods for polluted soils [14]. Mycorrhiza considered crucial component of soils that provide immunity for the plants growing in contaminated soils [15]. In addition to its role played in the provision of essential plant nutrients from the soil and saving the plants growing on dry soils, mycorrhizae help the plants to escape from heavy metal toxicities [15]. Numerous studies conducted collecting lead concentration data from both natural and contaminated soil 
on a range of scales. However, little attention have been paid to practical ways of transforming available $\mathrm{Pb}$ for plant to unavailable forms in soil. Present research done to study of compost effectiveness to control of $\mathrm{Pb}$ toxicity in soils.

\section{MATERIAL AND METHODS}

The area selected for the study is believed to be one of the most affected area by $\mathrm{Pb}$ contamination in soils [16]. Experimental area, Golestan national park witch situated in Golestan Province between the eastern parts of the Elburs Mountains and the western fringes of the Khorasan-Kopet Dag . The Golestan National Park was the first area in Iran to be designated as a national park that is located at $37,16^{\circ}$ to $37,36^{\circ}$ north latitude and $55,44^{\circ}$ to $56,17^{\circ}$ east longitude and has an area of about 91.000 hectares. The terrain is mountainous with altitude varying between 380 and 2819 meters [17].

Annual rainfall in the region is about $650 \mathrm{~mm}$ [17]. Temperatures are low, with an annual mean of $12^{\circ} \mathrm{C}$, and ground frost is common in February [17]. Ultisol Soil characterized by a thick, black, organic layer at the surface [17]. Twenty-four permanent plots of $20 \mathrm{~m} \mathrm{x} 20 \mathrm{~m}$ established to represent an affected area in the Golestan National Park. Randomized Complete Block Design (RCBD) used with three replications. A sketch of the area and the experimental plots mapped using GPS (Global Positioning System) points with $20 \mathrm{~cm}$ accuracy. The indicator plant used to identify the response to soil $\mathrm{Pb}$ was Anthemis Anthemis. Treatments applied to five randomly selected Anthemis Anthemis plant. They selected from each sampling plot. Four soil amendments (a). Compost-2kg/plants, (b). Compost and mycorrhizae-4kg/plants. (c). mycorrhizae- $2 \mathrm{~kg} / \mathrm{plants}$ including a control were used for the study. Lead in the soil samples was measured by wet ash method [18] and the extractants analyzed for the above elements by Atomic Absorption Spectrophotometry [19]. Soil sampling s done three times and the samples collected from $0.2 \mathrm{~m}$ depth and $0.3 \mathrm{~m}-0.5 \mathrm{~m}$ away from each plant. Death rates of the plants calculate by keeping records of the selected samples throughout the experimental period and counting the deaths at the end of the trial. SPSS statistical software used for the analysis of variance (ANOVA), t-test and regression analysis of the results.

\section{RESULTS}

The results showed based on the work done during the one-year study period in the Golestan National Park ,Iran Average values of the parameters were used to compare the effect of different treatments.

\section{A. Soil Organic Matter}

Addition of compost to soil increased SOM content in the soil (see Fig. 1). In addition, the effect of the treatments on SOM content was significant for all the four stages of sampling-e.g. Stage-1 $(p=<0.001)$, Stage- $2(p=<0.001)$, and Stage-3 $(<0.001)$ at the $0.2 \mathrm{~m}$ depth.

Treatments with mycorrhizae and the control showed the lowest SOM at all three stages. Across different stages at
$0.2 \mathrm{~m}$ depth, the highest SOM content exhibited in the Stage 2 but the statistical analysis under $\alpha$ level of 0.05 was not significant.

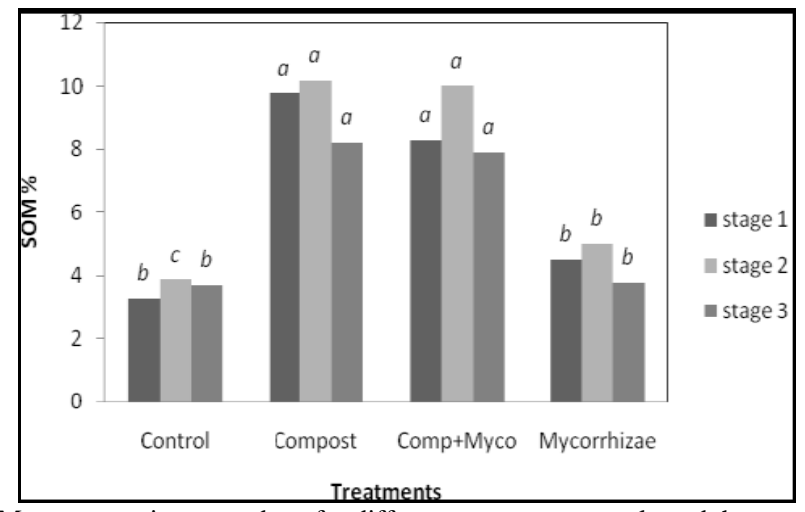

(Mean comparison was done for different seasons separately and the means appear with same letter were not significant at $p<0.05$ )

Fig. 1. Status of SOM percentage among the treatments at three different stages of sampling in $0.2 \mathrm{~m}$ depth.

\section{B. Lead in the Soil}

Results from both soil and foliar analysis clearly indicated the status of contamination of soil and the vegetation with $\mathrm{Pb}$ in Golestan park differences among the treatments were observed in terms of soil $\mathrm{Pb}$ level in $0.2 \mathrm{~m}$ depth during Season-1 $(p=0.01),-2(p=0.004)$ but there was no significant influence detected at Season-3 ( $p=0.79)$ (see Fig. 2). The highest $\mathrm{Pb}$ content detected in the control during Season-1 whereas, the lowest observed under the treatment mycorrhizae, again during Season-1. However, the control showed the highest soil $\mathrm{Pb}$ level during the Season-1 while the treatments compost, compost with mycorrhizae, and mycorrhizae showed significantly lower soil $\mathrm{Pb}$ levels compared to the control.

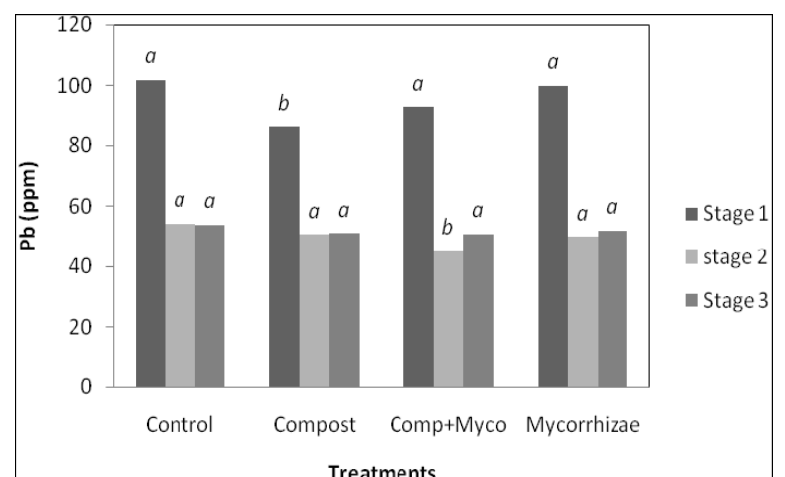

(Mean comparison was done for different seasons separately and the means appear with same letter were not significant at $p<0.05$ )

Fig. 2. Status of $\mathrm{Pb}$ among treatments at three different stages of sampling in $0.2 \mathrm{~m}$ depth.

\section{C. $P b$ in the Leaves}

TABLE I: VARIATION OF PB IN THE LEAVES FROM DIFFERENT TREATMENTS

\begin{tabular}{|l|l|l|l|l|}
\hline reatment & Control & compost & $\begin{array}{c}\text { Compost+ } \\
\text { mycorrhizae }\end{array}$ & mycorrhizae \\
\hline $\begin{array}{l}\mathrm{Pb}(\mathrm{ppm}) \\
\text { Mean }\end{array}$ & $4.133(0.04)$ & $2.1(0.0)$ & $4.217(0.05)$ & $4.217(0.02)$ \\
\hline
\end{tabular}

*Standard error for the respective mean given within brackets

Results from foliar analysis indicated the entry of $\mathrm{Pb}$ into the plant bodies (see Table I). When the levels of $\mathrm{Pb}$ in the 
soil considered, plots treated with mycorrhizae showed lower values when compared to the values observed in the other plots. Even though this decline was not statistically significant $(p=0.075)$ under $\alpha$ level of 0.05 , the results cannot be disregarded.

\section{Death Rate of Anthemis Anthemis Plants}

Soil amendments with standard compost and mycorrhizae are effective in controlling the death of Anthemis Anthemis plants. Treatment effect on the death rate of samples was significant $(p<0.001)$ and the control showed the highest death rate (see Table II).

TABLE II: VARIATION OF DEATH RATE OF ANTHEMIS ANTHEMIS PLANTS

\begin{tabular}{|l|l|l|l|l|}
\hline treatment & control & compost & $\begin{array}{l}\text { Compost+ } \\
\text { mycorrhizae }\end{array}$ & mycorrhizae \\
\hline $\begin{array}{l}\text { Death rate } \\
(\%) \\
(\text { Mean })\end{array}$ & $46.67(8.43)$ & $15.83(0.40)$ & $17.67(0.92)$ & $31.67(3.07)$ \\
\hline
\end{tabular}

*Standard error for the respective mean given within brackets

\section{E. Lead in the Soil and Death of Plants}

The relationship between $\mathrm{Pb}$ concentration and the death rate of Anthemis Anthemis samples was significant $(p<0.001)$ while the correlation showed the death rate of samples has been largely affected by the $\mathrm{Pb}$ concentration in the soil (see Fig. 3). Therefore, the death rate of the samples used for the experiment appeared to have increased with the increasing availability of $\mathrm{Pb}$ in the soil. Results further revealed that the crucial level of $\mathrm{Pb}$ in relation to the survival of Anthemis Anthemis samples was around $60 \mathrm{ppm}$ in the Golestan national park soil and beyond this level; even a slight increase of available $\mathrm{Pb}$ in the soil may impose severe damages on plant's metabolism leading to dieback. The results are in agreement with the work done by [20].

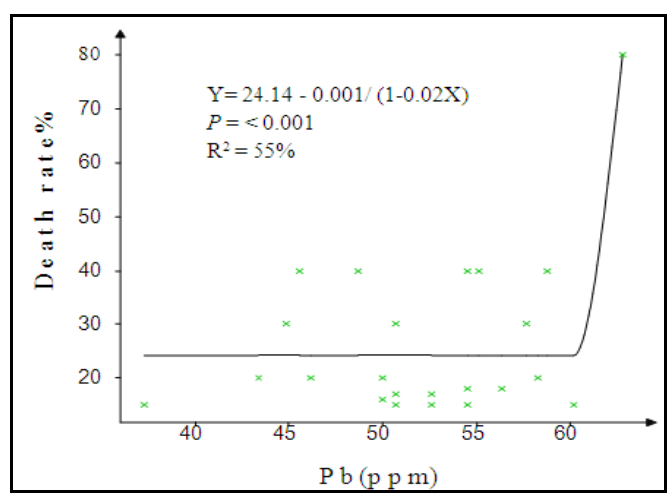

Fig. 3. Pb concentrations in the soil Vs Death rate of plants

\section{F. Lead (Pb) Concentrations in Soils vs $\mathrm{Pb}$ Concentrations in Foliage Parts}

Parallel to the increment of $\mathrm{Pb}$ levels in the soil, the $\mathrm{Pb}$ level in the leaves of Anthemis Anthemis plans have also increased. The relationship between soil $\mathrm{Pb}$ and the leaf $\mathrm{Pb}$ was significant $(p=0.01)$ and the nature of the relationship is linear - by -linear (see Fig. 4).

\section{G. Soil Organic Matter vs $\mathrm{Pb}$ in the Soil}

The content of soil $\mathrm{Pb}$ is inversely proportional to the SOM content and the relationship between them was statistically significant $(p=<0.001)$. The findings indicate that the availability of $\mathrm{Pb}$ in the soil for plants in the can be reduced by increasing SOM level. The nature of the decline of $\mathrm{Pb}$ with the increasing SOM level seems to be linear by linear (see Fig. 5). Immobilization of soluble $\mathrm{Pb}$ in the soil by the humic and fulvic acid molecules presented in some documented studies by several researchers (e.g., [21]).

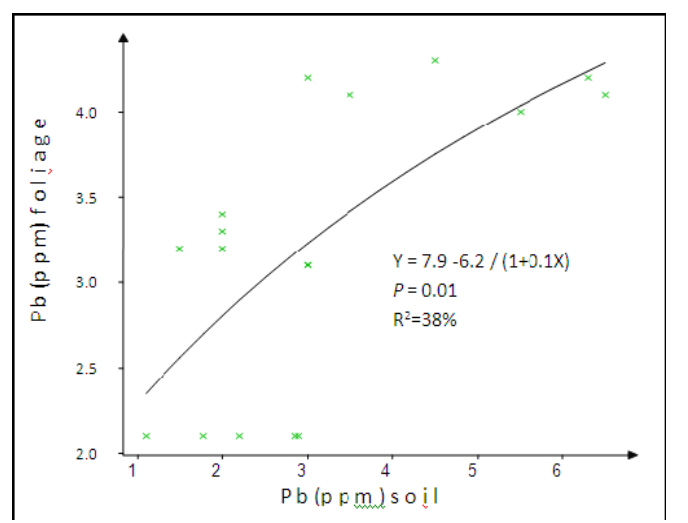

Fig. 4. $\mathrm{Pb}$ concentrations in soils $\mathrm{Vs} \mathrm{Pb}$ concentrations in foliage.

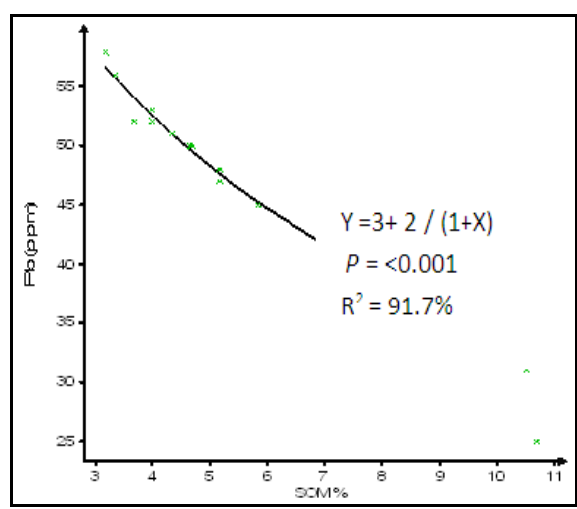

Fig. 5. Soil organic matter $\mathrm{Vs} \mathrm{Pb}$ in the soil at four different stages.

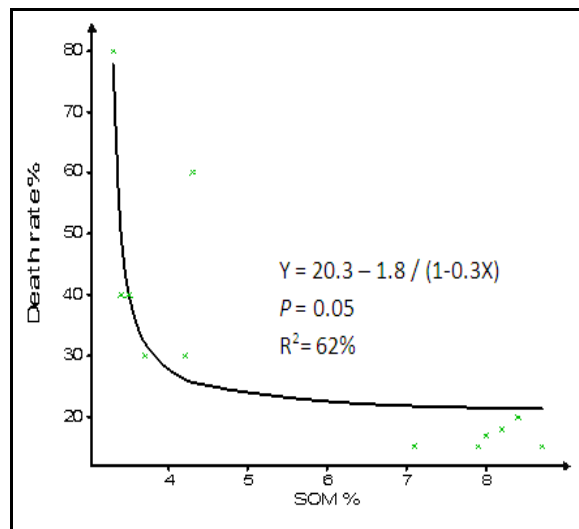

Fig. 6. Soil organic matter content in the soil vs Death rate of plants.

\section{H. Soil Organic Matter Content in the Soil and Dieback of Plants}

Results showed that the increase of SOM level helps to reduce the death of plants. The relationship between SOM level and the death rate of samples (Anthemis Anthemis) was significant $(p=0.05)$. The nature of the relationship seems to be linear-by-linear and it further indicates that by maintaining SOM level somewhere above $4 \%$, the death rate of samples can reduce significantly (see Fig. 6).

\section{DISCUSSION}

Deterioration of the level and the quality of soil organic 
matter in terms of humic substances appears to have influenced on the development of $\mathrm{Pb}$ toxicity. The death of plants may be related to dozens of reasons, which include $\mathrm{Pb}$ toxicity as well. Effect of the treatments consisted of SOM justify the argument. One of the most important fractions of SOM, the humic substances, is highly effective in neutralizing the effects of toxic substances (e.g. $\mathrm{Pb}$ ) in the soil [21]. The lower the level of SOM, the higher the level of plant available soil $\mathrm{Pb}$ and therefore, the enrichment of soils in affected areas with quality organic matter with standard levels of humic substances can be recommended to control $\mathrm{Pb}$ toxicity in the soil. This argument confirmed by the death rate of the samples where the results show that the lowest level of SOM represents the highest death rate. The level of soil $\mathrm{Pb}$ has gone up to $106 \mathrm{ppm}$. However, it should be noted that the maximum allowable limit for soil $\mathrm{Pb}$ is about 100 ppm [22]. Even the smallest amount of $\mathrm{Pb}$ may impose severe damages on plant's metabolism leading to death. Lead $(\mathrm{Pb})$ at toxic levels identified as an agent causing damages on plants' respiratory mechanism in particular. [20]. Burning diesel, gasoline and lubricants releases $\mathrm{Pb}$ to the atmosphere. Additionally, the frictions in brake pads, clutch liners and tires release these elements to the atmosphere. Flows of water flood from rainfall seem to be the most possible transportation source of $\mathrm{Pb}$ from the polluted part. Following last studies, $\mathrm{Pb}$ subjected to long-range atmospheric transportation to greater extent [23] where $\mathrm{Pb}$ can transport for a distance greater than $120 \mathrm{~km}$ [24]. Therefore; it is very unlikely that the rain falling onto the area is free from $\mathrm{Pb}$. When the levels of $\mathrm{Pb}$ in the soil are considered, plots treated with mycorrhizae showed lower values than the values observed in the other plots. Even though this decline is not statistically significant for less than $\alpha=0.05$, the results cannot be ignored. Mycorrhizae significantly increase the absorption of various elements from the soil including heavy metals such as $\mathrm{Pb}$ [25]. Therefore, it can be assume that mycorrhizae are responsible for reduction of $\mathrm{Pb}$ in the soil treated with mycorrhizae. Mycorrhiza considered a crucial component of soils that provide immunity for the plants growing in contaminated soils [15]. Therefore, mycorrhizal treatment may have been effective in increasing the tolerability of plants growing in contaminated soils with $\mathrm{Pb}$.

\section{ACKNOWLEDGMENT}

This study was conducted with the support of the Department of Environment; University of Golestan. Our very special appreciation should go Mr.Mahmoudi for helping us to complete laboratory analysis related to the research.

\section{REFERENCES}

[1] N. Mollazadeh, "Metals health risk assessment via consumption of vegetables," Intl. J. Agri. Crop. Sci., vol. 7, no. 8, pp. 433-436, 2014.

[2] N. Mollazadeh, A. Esmaili, and M. Ghasempouri, "Distribution of Mercury in Some Organs of Anzali wetland Common cormorant (Phalacrocorax carbo)," International Proceeding of Chemical, Biological and Environmental Engineering, vol. 17, pp. 190-194, 2011.

[3] N. Mollazadeh, F. Moattar, and A. R. Karbassi, "Distribution of metals, chemical partitioning, pollution and origins in riverbed sediment," World Applied Sciences Journal (WASJ), vol. 21, pp. 674-680, 2013.

[4] S. D. Sithole, N. Moyo, and J. Macheka, "An assessment of lead pollution of vehicle emissions along selected roadways in Harare (Zimbabwe)," Intern. J. Environ. Anal. Chan., vol. 53, pp. 1-12, 1993.
[5] F. Monacci and R. Bargali, "Barium and other metals as indicator of vehicle emissions," Water Air Soil. Pollut., vol. 100, pp. 89-98, 1997.

[6] B. E. Davies, "Lead," in Heavy in Soils, B. J. Alloway, Ed. London: Blackie Academic professional, 1995, pp. 206-223.

[7] A. Kabata-Pendias and H. Pendias, Trace Elements in Soils and Plants, 2nd ed., CRC Press, Boca Raton Ann Arbor, London, 1992

[8] D. C. Adriano, "Trace elements in terrestrial environments," in Biogeochemistry, Bioavailability, and Risks of Metals, 2nd ed., New York: Springer-Verlag, 2001

[9] C. Angehrn-Bettinazzi, L. Thoni, and J. Hertz, "An attempt to evaluate some factors affecting the heavy metal accumulation in a forest stand," Int. J. Environ. Anal. Chem, vol. 35, pp. 69-79, 1989.

[10] A. Datta, S. K. Sanyal, and S. Saha, "A study of natural and synthetic humic acids and their complexing ability towards cadmium," Plant Soil, vol. 235, pp. 115-125, 2001.

[11] D. V. Ladonin and S. E. Margolina, "Interaction between humic acids and heavy metals," Eurasian Soil Sc.i, vol. 30, pp. 710-715, 1997.

[12] V. P. Evangelou and M. Marsi, "Composition and metal ion complexation behavior of humic fractions derived from corn tissue," Plant Soil, vol. 229, pp. 13-24, 2001.

[13] M. Arias, M. T. Barral, and J. C. Mejuto, "Enhancement of copper and cadmium adsorption on kaolin by the presence of humic acids," Chemosphere, vol. 48, pp. 1081-1088, 2002.

[14] M. Halim, P. Conte, and A. Piccolo, "Potential availability of heavy metals to phytoextraction from contaminated soils induced by exogenous humic substances," Chemosphere, vol. 52, pp. 265-275, 2003.

[15] A. Gaur and A. Adholeya, "Prospects of arbuscular mycorrhizal fungi in phytoremediation of heavy metal contaminated soils," Current Science, vol. 86, pp. 528-534, 2004.

[16] P. N. Ranasinghe, C. B. Dissanayake, D. V. N. Samarasinghe, and R Galappatti, "The relationship between soil Geochemistry and Dieback of montane forests in Sri Lanka - A case study," Environmental Geology, 2006.

[17] B. Hassanzadeh, B. Zehzad, B. Farhang, H. Majnounian, and H Goshtasb, Golestan National Park, Department of Environment, Fardin Publication, pp. 203, 1993.

[18] USEPA, Method 3050B, Acid Digestion of Sediments, Sludges and Soils, 1996.

[19] E. Dale and H. Norman, "Atomic absorption and flame emission spectrometry," in Methods of Soil Analysis, 2nd ed. A. L. Miller, R. H. Keeney et al., Eds. Madison, WI, USA : Agronomy 9, American Society of Agronomy Inc., 1982, vol. 2, pp. 13-27.

[20] A. B. Pahlsson, "Toxicity of heavy metals ( $\mathrm{Zn}, \mathrm{Cu}, \mathrm{Cd}, \mathrm{Pb})$ to Vascular Plants," Water Air Soil Poll, vol. 47, pp. 287-319, 1989.

[21] J. Drozd, S. S. Gonet, N. Sensei, J. Weber, and I. Pavasaras, "Complexsation of Europium by an Aquatic Fulfic Acid: Iron as a Compering Ion," The Role of Humic Substances in the Ecosystems and in Environmental Protection, Wroclaw, Poland, 1997.

[22] A. Kloke, "Orientierungsdaten für tolerierbare gesamtgehalte einiger elemente in kulturboden mitt.," VDLUFA, 1980, H.1-3: 9-11.

[23] E. Steinnes, J. P. Rambaek, and J. E. Hanssen, "Large scale multielement survey of atmospheric deposition using naturally growing moss as biomonitor," Chemosphere, vol. 35, pp. 735-752, 1992.

[24] M. F. Billett, E. A. Fitzpatrick, M. S. Cresser, "Long term changes in the $\mathrm{Cu}, \mathrm{Pb}$ and $\mathrm{Zn}$ content of forest soil organic horizons from North East Scotland," Water Air Soil Poll., vol. 59, pp. 179-191, 1991.

[25] L. Weissenhorn, C. Leyval, and J. Berthelin, "Bioavailability of heavy metals and abundance of arbuscular mycorrhiza in soil polluted by atmospheric deposition from a smelter," Biol. Fert. Soils, vol. 19, 1995.

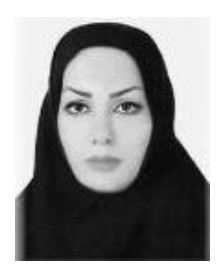

N. Mollazadeh is the head of department, and an assistant professor in the Dept. of Environment, Najafabad Branch, Islamic Azad University.

Nastaran Mollahzadeh is working as an environmental problem researcher for about 11 years. She started her cooperation as a full time professor and researcher with the Islamic Azad University since 2008. Her major research areas are in environmental quality, pollution study and control (including soil, sediment and water pollution), modeling and simulation of environmental pollutions. The major focus of her researches are on heavy metal contamination, bio-accumulation and metal's toxicology.

She also investigates on marine pollution. Her special interest is on fresh water quality and health. She has carried out sample works on air pollution and waste management in Iran. She also has worked on pollution from power plants. 